\title{
An empirical investigation on factors influencing on quality of work life
}

\author{
Alireza Davoudzadeh Mogaddam and Naser Azad*
}

Department of Management and Accounting, South Tehran Branch, Islamic Azad University, Tehran, Iran

\begin{tabular}{l}
\hline C H R O N I C L E \\
\hline Article history: \\
Received March 18, 2015 \\
Accepted May 25 2015 \\
Available online \\
May 26 2015 \\
\hline Keywords: \\
Quality of work life \\
Organization \\
Factor analysis
\end{tabular}

\section{Introduction}

It is safe to describe our age as the age of organizations. Organizations of various types and sizes have become a dominant type of institution everywhere (Al-Qutop \& Harrim, 2011). During the past few years, quality of work life has received significant attention from both academic and business environments due to its vital role on the success of organizations. Quality of work life (QWL) is quick phrase that encompasses a lot, because it refers to virtually anything an employer does that contributes to employees' lives (Nasl Saraji \& Dargahi, 2006). Quality of work life is one of the most important issues in every organization (Muhamad Noor \& Adli Abdullah, 2012). A perfect quality of work life would help most organizations. Rise in the quality of work life would help employees' well-being thereby the well-being of the whole organization. This is an attempt to capitalize the human assets of the organization (Bharathi et al., 2011). These days, for an organization to be successful and achieve its organizational objectives it is imperative that its employees are satisfied with their works, since work

\begin{abstract}
During the past few years, quality of work life has received significant attention among both academic and business environments due to its vital role on the success of organizations. Rise in the quality of work life would help employees' well-being thereby the well-being of the days, for an haman assets of the organization. These imperative that its employees are satisfied with their work, since work occupies an important place in many people's lives, such conditions are likely to affect not only their physical but also a high level of social, psychological and spiritual well-being. The proposed study designed a questionnaire and distributed among 192 experts in the largest automotive producer in Iran called Iran Khodro and managed to collect 175 filled ones. The questionnaire consists of 24
questions and Cronbach alpha was calculated as 0.81 , which is well above the minimum acceptable limit and validates the results. The results of our survey indicate that four major factors including job characteristics, working conditions, organizational characteristics and human relations influence quality of work conditions.
\end{abstract}


occupies an important place in many people's lives, such conditions are likely to affect not only their physical but also a high level of social, psychological and spiritual well-being (Sinha, 2012).

Historically, work has been an important part in the life of human beings (Nadler \& Lawler, 1984; Kanten \& Sadullah, 2012). QWL has been originated from an international labor relations conference in 1972 at Arden House, Columbia University, New York (Davis \& Cherns, 1975; Guest, 1979; Sinha, 2012; Cascio \& Thacker, 1992). The evolution of QWL began in late 1960s emphasizing the human dimensions of work by concentrating on the quality of the relationship between the worker and the working environment (Che Rose et al., 2004).

Ever since the concept of QWL was first used over 30 years ago, ranges of definitions and theoretical constructs have succeeded each other with the aim of mitigating the many problems facing the concept (Martel \& Dupuis, 2006; Mirkamali \& Narenji Thani, 2011). Straw and Heksher (1984) and Tabassum et al. (2011), QWL is a philosophy, a set of principles, which holds that people are the most important resource in the organization as they are trustworthy, responsible and capable of making valuable contribution and they should be treated with dignity and respect.

It is a complex, multidimensional, generic concept (Hsu \& Kernohan, 2006; Gayathiri \& Ramakrishnan, 2013). Quality of work life also refers to the favorableness or unfavourableness of a job environment for people. It is a generic phase that covers person's feelings about every dimension of work including economic rewards and benefits, security, working conditions, organization and interpersonal relationship and its intrinsic meaning in a person's life (Kraut et al., 1989; Rathamani \& Ramchandra, 2013). QWL has also been viewed in a variety of ways including as a movement, as a set of organizational interventions and a type of work life by employees (Saraji \& Dargahi, 2006). QWL is defined as "employee satisfaction with a variety of needs through resources, activities, and outcomes stemming from participation in the workplace” (Sirgy et al., 2001; Marta et al., 2013).

According to Suttle and Hackman (1977), “quality of work life is the degree to which members of a work organization are able to satisfy important personal needs through their experiences in the organization”. More specifically, quality of work life may be set into operation in terms of employee's perceptions of their physical and psychological well-being at work (Priyadarshani \& Bhagat, 2014).

Some people stated that the quality of work life had an effect on employees' life and working environment. QWL provides for the balanced relationship among work, non- work and family aspects of life. Others stated that quality of working life enables members at all levels to actively participate in shaping the organization environment, methods and outcomes (Rathamani \& Ramchandra, 2013).

Quality of work life is often considered in two directions, one is to removal of negative aspects of work and working conditions and other direction is the modification of work and working conditions to enhance the capability of employees and to promote behavior which important for individual and Society (Cohen et al., 1997; Kotzé, 2005; Ford \& Kotzé, 2005).

Focusing on improving QWL to increase the happiness and satisfaction of employees can result in many advantages for the employee, organization and consumers (Almalki et al., 2012; Islam, 2012), due to this advantages quality of work life in one of the most significant issues in every modern organization.

\section{Proposed Study}

This paper presents a study to find important factors influencing on quality of work life using factor analysis. The proposed study of this paper designs a questionnaire, which consists of 24 questions in Likert scale and distributes it among 194 employees who work for the largest automotive producer in Iran called Iran Khodro and managed to collect 175 filled ones.

Cronbach alpha, Kaiser-Meyer-Olkin Measure of Sampling adequacy and Bartlett's test of Sphericity approximation Chi-Square are 0.81, 0.679 and 844.475, respectively and they are within acceptable 
limit. The four influencing factors are job characteristics, working conditions, organizational characteristics and human relations which are presented in details in next section.

\section{The results}

In this section, we present details of four factor extracted from factor analysis.

\subsection{The first factor: Job characteristics}

The first factor, job characteristics, consists of four factors including responsibility, adequate payment, division of labor and autonomy. Table 1 demonstrates the summary of our findings.

\section{Table 1}

Factors associated with job characteristics

\begin{tabular}{lcccc}
\hline Option & Factor weight & Eigen values & \% of variance & Accumulated \\
\hline Responsibility & 0.869 & & & \\
Adequate payment & 0.852 & & & \\
Division of labor & 0.541 & & 49.407 & 49.407 \\
Autonomy & 0.883 & 1.976 & 4 \\
\hline
\end{tabular}

As we can observe from the results of Table 1, the last factor, autonomy, maintains the highest factor weight, 0.883 , followed by responsibility, adequate payment and division of labor and it could explain $49.407 \%$ of variance.

\subsection{The second factor: Working condition}

Working condition is the second factor of this survey, which includes health hazard issues, alternative work schedule, and shift working regulations and working hours. Table 2 demonstrates the summary of our findings.

\section{Table 2}

The summary of factors associated with working conditions

\begin{tabular}{lllll}
\hline Option & Factor weight & Eigen values & \% of variance & Accumulated \\
\hline Health hazard issues & 0.624 & & & \\
Alternative work schedule & 0.838 & & & \\
Shift working regulations & 0.846 & 2.259 & 44.483 & 44.483 \\
Working hours & 0.342 & & & \\
\hline
\end{tabular}

As we can observe from the results of Table 2, the impact of shift working regulations, maintains the highest factor weight, 0.846 , followed by alternative work schedule, health hazard issues and working hours and it could explain $44.483 \%$ of variance.

\subsection{The third factor: Organizational characteristics}

Organizational characteristics is the third factor of this survey, which includes stress, growth in the profession path, organizational conflict, evaluation methods, organizational justice, opportunities to learn and financial and non-financial benefits. Table 3 demonstrates the summary of our findings. As we can see from the results of Table 3 , the impact of growth in the profession path maintains the highest factor weight, 0.762, followed by organizational justice, financial and non-financial benefits, organizational conflict, evaluation methods, opportunities to learn and stress, and it could explain $38.061 \%$ of variance. 


\section{Table 3}

The summary of factors associated with organizational characteristics

\begin{tabular}{lllll}
\hline Option & Factor weight & Eigen values & \% of variance & Accumulated \\
\hline Stress & 0.586 & & & \\
Growth in the profession path & 0.762 & 1.526 & 38.061 & 38.061 \\
Organizational conflict & 0.674 & & & \\
Evaluation methods & 0.634 & & & \\
Organizational justice & 0.750 & & & \\
Opportunities to learn & 0.593 & & & \\
$\begin{array}{l}\text { Financial and non-financial } \\
\text { benefits }\end{array}$ & 0.712 & & & \\
\hline
\end{tabular}

\subsection{The fourth factor: Human relations}

Human relations is the fourth factor of this survey, which includes teamwork, Superior-subordinate relations and organizational structure. Table 4 demonstrates the summary of our findings.

Table 4

The summary of factors associated with human relations

\begin{tabular}{lllll}
\hline Option & Factor weight & Eigen value & \% of variance & accumulated \\
\hline Teamwork & 0.579 & & & \\
Superior-subordinate relations & 0.695 & 1.539 & 51.302 & 51.302 \\
Organizational structure & 0.636 & & & \\
\hline
\end{tabular}

According to the results of Table 4, the impact of superior-subordinate relations maintains the highest factor weight, 0.695 , followed by organizational structure and teamwork.

\section{Conclusion}

In this paper, we have presented an empirical investigation to study important factors influencing on quality of work life in Iranian automotive industry. The proposed model of this paper used factor analysis and detected four important factors including job characteristics, working condition, organizational characteristics and human relations.

In terms of job characteristics, autonomy is number one priority followed by responsibility, adequate payment and division of labor. In terms of working conditions, shift working regulations is the most important factor followed by alternative work schedule, health hazard issues and working time.

In terms of organizational characteristics, growth in the profession path is the most important factor followed by organizational justice, financial and non-financial benefits, organizational conflict, evaluation methods, and opportunities to learn and finally, stress was the last important one. In terms of human relations, superior-subordinate relations followed by organizational structure and teamwork.

\section{Acknowledgment}

The authors would like to thank Iran Khodro for cordially supporting this research. We are also delighted for constructive comments on earlier version of this paper.

\section{References}

Al-Qutop, M. A. Y., \& Harrim, H. (2011). Quality of worklife human well-being linkage: integrated conceptual framework. International Journal of Business and Management, 6(8), p193-205. 
Almalki, M. J., FitzGerald, G., \& Clark, M. (2012). Quality of work life among primary health care nurses in the Jazan region, Saudi Arabia: a cross-sectional study. Human resources for health, 10(1), 30.

Islam, M. B. (2012). Factors affecting quality of work life: an analysis on employees of private limited companies in Bangladesh. Global Journal of Management and Business Research, 12(18), 22-31

Bharathi, P. S., Umaselvi, M., \& Kumar, N. S. (2011). Quality of Work Life: Perception of College Teachers. Indian Journal of Commerce \& Management Studies, 2(1), 47-65.

Cascio, W. F., \& Thacker, J. W. (1992). Managing human resources: Productivity, quality of work life, profits (Vol. 2). New York, NY: McGraw-Hill.

Che Rose, R., Uli, J., Abdul, M., \& Looi Ng, K. (2004). Hospital service quality: a managerial challenge. International Journal of Health Care Quality Assurance,17(3), 146-159.

Cohen, S. G., Chang, L., \& Ledford, G. E. (1997). A hierarchical construct of self-management leadership and its relationship to quality of work life and perceived work group effectiveness. Personnel Psychology, 50(2), 275-308.

Ford, G., \& Kotzé, P. (2005). Designing usable interfaces with cultural dimensions. In Humancomputer interaction-INTERACT 2005 (pp. 713-726). Springer Berlin Heidelberg.

Guest, R. H. (1979). Quality of work life, learning from Tarrytown. Harvard University Graduate School of Business Administration.

Rose, R. C., Beh, L., Uli, J., \& Idris, K. (2006). Quality of work life: implications of career dimensions. Journal of Social Sciences, 2(2), 61-67.

Gayathiri, R., Ramakrishnan, L., Babatunde, S. A., Banerjee, A., \& Islam, M. Z. (2013). Quality of work life-Linkage with job satisfaction and performance.International Journal of Business and Management Invention, 2(1), 1-8.

Hsu, M. Y., \& Kernohan, G. (2006). Dimensions of hospital nurses’ quality of working life. Journal of advanced nursing, 54(1), 120-131.

Kanten, S., \& Sadullah, O. (2012). An empirical research on relationship quality of work life and work engagement. Procedia-Social and Behavioral Sciences,62, 360-366.

Kotzé, M. (2005). The nature and development of the construct "quality of work life". ACTA Academica-University of the Free State, 37(2), 96.

Kraut, R. E., Dumais, S. T., \& Koch, S. (1989). Computerization, productivity, and quality of worklife. Communications of the ACM, 32(2), 220-238.

Martel, J. P., \& Dupuis, G. (2006). Quality of work life: theoretical and methodological problems, and presentation of a new model and measuring instrument. Social Indicators Research, 77(2), 333-368.

Marta, J. K., Singhapakdi, A., Lee, D. J., Sirgy, M. J., Koonmee, K., \& Virakul, B. (2013). Perceptions about ethics institutionalization and quality of work life: Thai versus American marketing managers. Journal of Business Research,66(3), 381-389.

Mirkamali, S. M., \& Thani, F. N. (2011). A study on the quality of work life (QWL) among faculty members of University of Tehran (UT) and Sharif University of Technology (SUT). Procedia-Social and Behavioral Sciences, 29, 179-187.

Nadler, D. A., \& Lawler, E. E. (1984). Quality of work life: perspectives and directions. Organizational dynamics, 11(3), 20-30.

Noor, S. M., \& Abdullah, M. A. (2012). Quality work life among factory workers in Malaysia. Procedia-Social and Behavioral Sciences, 35, 739-745.

Priyadarshani, S., \& Bhagat, M. (2014). Quality of work life balance: one lives to work or works to live. Journal of Exclusive Management Science, 3(1), 1-7.

Rathamani, P., \& Ramachandra, R. (2013). A study on quality of work life employees in textile industry. IOSR Journal of Business and Management. 8(3), 54-59.

Saraji, G. N., \& Dargahi, H. (2006). Study of quality of work life (QWL). Iranian journal of public health, 35(4), 8-14.

Sinha, C. (2012). Factors affecting quality of work life: empirical evidence from Indian organizations. Australian Journal of Business and Management Research. 1(11), 31-40. 
Sirgy, M. J., Efraty, D., Siegel, P., \& Lee, D. J. (2001). A new measure of quality of work life (QWL) based on need satisfaction and spillover theories. Social Indicators Research, 55(3), 241-302.

Suttle, J. L., \& Hackman, J. R. (Eds.). (1977). Improving life at work: Behavioral science approaches to organizational change. Goodyear.

Tabassum, A., Rahman, T., \& Jahan, K. (2011). Quality of work life among male and female employees of private commercial banks in Bangladesh. International Journal of Economics and Management, 5(1), 266-282. 